\title{
Particulate air pollution from motor vehicles: \\ A putative proallergic hazard?
}

\author{
Riccardo Polosa MD PhD ${ }^{1}$, Sundeep Salvi MD DNB ${ }^{2}$ \\ ${ }^{1}$ Instituto Malattie Apparato Respiratorio, Universita' de Catania, Ospedale Tomaselli, \\ Catania, Italy; ${ }^{2}$ University Medicine, Southamptom General Hospital, Southampton, \\ United Kingdom
}

\section{R Polosa, S Salvi. Particulate air pollution from motor ve- hicles: A putative proallergic hazard? Can Respir J 1999:6(5):436-441.}

Air pollution generated from motor vehicle exhaust has become a major cause for scientific and public concern worldwide over recent years. The rapid and marked increase in the motor vehicle traffic and its associated emissions in urban areas have paralleled a sharp increase in the prevalence of allergic diseases such as asthma and rhinitis. Epidemiological studies have demonstrated a strong association between people living in close proximity to roads with high traffic density and increased allergic symptoms, reduced lung function and increased sensitization to common aeroallergens. Several laboratory-based studies have demonstrated that pollutants emitted from motor vehicles can induce allergic inflammation and increase airway hyperresponsiveness, which may provide an underlying mechanism for the increasing prevalence of allergic diseases. Although the detrimental effects of air pollution on human health have been brought to public attention, it appears that less attention has been given to the potential role of road traffic fumes in the induction of the allergic state. Legislators should consider pollutants emitted from motor vehicle exhausts as a potential pro-allergic hazard, before making important changes in environmental policy.

Key Words: Allergy; Epidemiology; Diesel exhaust; Immunoglobulin E; Immunology; Road traffic pollution

\section{Pollution de l'air par des particules en suspen- sion provenant des véhicules à moteur : un dan- ger pro-allergique putatif ?}

RÉSUMÉ : La pollution de l'air générée par les gaz d'échappement des véhicules à moteur est, depuis ces dernières années, devenue un sujet de préoccupation important pour les scientifiques et la population du monde entier. L'augmentation marquée et rapide de la circulation de véhicules à moteur et de leurs gaz d'échappement dans les zones urbaines est parallèle à l'augmentation significative de la prévalence des maladies allergiques comme l'asthme et la rhinite. Les études épidémiologiques ont démontré une forte association entre le fait d'habiter près des routes à forte densité de circulation et une augmentation des symptômes d'allergie, une diminution de la fonction pulmonaire et une augmentation de la sensibilisation à des aéroallergènes courants. Plusieurs études de laboratoire ont démontré que les polluants émis par les véhicules à moteur peuvent induire une inflammation d'origine allergique et provoquer une hyperréactivité bronchique, qui pourraient fournir un mécanisme sous-jacent à l'augmentation de la prévalence des maladies allergiques. Bien que l'on ait sensibilisé la population aux effets nocifs de la pollution de l'air sur la santé humaine, on s'est moins attardé sur le rôle potentiel des gaz d'échappement provenant du trafic routier comme déclencheur de l'état allergique. Les législateurs devraient considérer les polluants émis par les gaz d'échappement des véhicules à moteur comme un danger pro-allergique potentiel avant de modifier en profondeur les politiques environnementales. 
A ir pollution is currently the subject of widespread debate in the scientific, political and social arenas. In the past, the effects of air pollution on human health were brought to public notice by major environmental incidents such as the London smog episode of 1952, in which over 4000 people died over a two-week period (1), and similar episodes before that, in the Meuse Valley of Belgium in 1930 (2) and in Donora, Pennsylvania in 1948 (3). These episodes was followed by the introduction of Clean Air Acts in the United Kingdom in 1956 and 1968, and in the United States in 1955 and 1963, which led to significant decreases in the levels of traditional pollutants (carbon black and sulphur dioxide).

However, over the past four decades the global vehicular fleet has increased 10-fold, leading to the generation of newer forms of air pollutants, in particular, ozone precursors, (such as oxides of nitrogen), volatile organic compounds, particulate matter, nitrogen dioxide, benzene, aldehydes, 1,3-butadiene and polyaromatic hydrocarbons (4). Estimates by the United Nations indicate that over 600 million people living in cities and towns around the world are exposed to unhealthy and dangerous levels of motor vehicle generated air pollutants (5). The number of vehicles is further expected to double over the next 20 to 30 years when the levels of these pollutants are predicted to increase even further. This rapid and marked expansion in motor vehicle traffic and its associated emissions have paralleled a worldwide increase in the prevalence of allergic diseases such as asthma and rhinitis. While genetic factors are important in the development of allergy, this rapid increase over the past two decades can only be explained by changes occuring in the environment, be it in the dwellings in which we live, the food we eat or the air we breathe (6). There is evidence to suggest that the rising levels of air pollutants may at least partly explain the increase in the prevalence of allergic diseases from motor vehicles $(7,8)$.

\section{EPIDEMIOLOGICAL EVIDENCE FOR AIR POLLUTION FROM MOTOR VEHICLES AND ALLERGY}

Among the various pollutants emitted from motor vehicle exhausts, particulate matter has generated major scientific and public concern (9). Although the sources of particulate matter vary from place to place and time to time, the largest single source of airborne particulate matter is that derived from diesel exhaust. This increase is not only because of a sharp increase in the number of diesel vehicles, but also because of the large amount of particles generated from diesel engines. Diesel vehicles emit up to 100 times more particles than those released from catalyst-equipped gasoline cars of corresponding performance (10).

Epidemiological studies in several countries have investigated the relationship between exposure to outdoor trafficrelated pollutants and respiratory health of potentially vulnerable groups by using three main types of exposure indicators: proximity of residence to main roads with heavy traffic, estimates of traffic density and modelled pollution level. Earlier studies in Japan by Ishizaki et al (11), Yokoyama et al
(12) and Ono et al (13) have shown that people living close to main roads with heavy traffic suffered more respiratory symptoms and allergies than those living further away. Studies carried out in The Netherlands $(14,15)$ and Canada (16) have reported increased respiratory symptoms and reduced lung function in those children living in close proximity to roads with high traffic density, which positively correlated with the levels of particulate matter in the ambient atmosphere. Asthmatic children, in particular, appear to be more susceptible to the adverse effects of particles than healthy children (16). Similar studies carried out in the United Kingdom (17) have demonstrated comparable findings. In general, children living or studying close to main roads suffer greater symptoms of cough and wheeze, show lower lung function measurements and increased bronchial hyperresponsiveness to methacholine compared with children living or studying further away (18-20). Children living in a highly polluted city of northern Bohemia in the Czech Republic have been shown to have chronically depressed lung function (21). Asthmatic patients, in particular, appear to be more vulnerable to the adverse effects of polluted air (22).

However, a number of studies have failed to show a clear association between respiratory symptoms and treatment of asthma, and the proximity of residence to main roads with heavy traffic $(23,24)$. Recently, Brunekreef et al (25) reported that children living in six areas located near major motorways in The Netherlands showed increases in respiratory symptoms and decreases in lung function measurements, with the largest decrease seen in those living within $100 \mathrm{~m}$ from the motorways (25). This decrease correlated significantly with truck traffic density but not with automobile traffic density. Similar results have been obtained from school children in Germany (26) and Italy (27), and from women residing in Tokyo (28). In Germany, Wjst et al (19) found no association between mean daily traffic volume in school districts and the lifetime prevalence of asthma in children aged nine to 11 years, but they did find an increased prevalence of breathlessness and reduced respiratory function with increased level of road traffic. A significant positive association has been shown between self-reported truck traffic and self-reported prevalence of wheezing and allergic rhinitis among secondary school-aged children (26) and adolescents (29), although possible reporting bias may be a particular problem with these studies.

Some authors have used modelled estimates of common motor vehicle-generated air pollutants at residence as markers of exposure to traffic-related pollutants. By using this approach, Pershagen et al (30) found an excess risk of hospitalization for wheezing illness in relation to timeweighted mean outdoor nitrogen dioxide exposure. Recently, Boezen et al (31) demonstrated that, in children with bronchial hyperresponsiveness and high levels of serum total immunoglobulin (Ig) E, the prevalence of respiratory symptoms increased up to $139 \%$ for every $100 \mu \mathrm{g} / \mathrm{m}^{3}$ increase in airborne particulate matter. Also, the large European Unionfunded Small Area Variations in Air Quality and Health (SAVIAH) study has provided additional information on 
modelled estimates of nitrogen dioxide and sulphur dioxide on a small-area scale (as a proxy for traffic-related pollutants), and prevalence of wheezing symptoms and asthma among school-aged children (32). No significant associations were found between the estimated outdoor air pollution at the residence of the child and respiratory symptoms. Although the SAVIAH study stands out as an original approach to the investigation of chronic health effects of traffic-related pollution and particularly of those aspects relating to exposure at a population level, a number of methodological flaws, such as the limited nature of the health assessment based on parent recall of symptoms by questionnaire, limit its interpretation.

Recently, several east-west comparisons of the prevalence of atopic diseases have shown a higher prevalence of hay fever and a higher prevalence of positive skin-tests to common allergens in school children living in Western Europe than in those living in Eastern Europe $(33,34)$. A possible explanation is that living conditions in the west, in particular air pollution from automobile exhaust, may be responsible for an increased prevalence of atopy. Other studies have compared the prevalence of atopy in populations living in urban and rural areas. The second National Health and Nutrition Examination Survey (35) has shown a higher prevalence of skin test reactivity in white Americans living in urban than those living in rural areas (35). High levels of specific IgE were found in $43.7 \%$ of urban and $32.6 \%$ of the rural probands, a difference that was statistically significant (36). In Sweden, Braback et al (37) demonstrated that $31 \%$ of the urban, but only $19 \%$ of the rural school children were atopic. Although road traffic pollution from automobile exhausts may be implicated as a risk factor for atopic sensitization, there is little published evidence to support this view. Polosa et al (38) have recently reported an increase in the proportion of positive cutaneous IgE-mediated responses in 234 traffic wardens with a well defined occupational history of exposure to road traffic fumes. In addition, when statistical analysis was restricted to nonsmokers, the difference was more evident.

\section{MECHANISMS OF DIESEL EXHAUST-INDUCED INCREASED ALLERGIC RESPONSES}

The mass median diameter of particles emitted from diesel exhaust particles (DEPs) are approximately $0.2 \mu \mathrm{m}$, with $90 \%$ of particles being less than $1 \mu \mathrm{m}$ by mass and $80 \%$ being approximately $0.1 \mu \mathrm{m}(10,39)$. These small particles, by virtue of their greater surface area to mass ratio, can carry a much larger fraction of toxic compounds such as polyaromatic hydrocarbons and their derivatives, along with several transition metals on their surface. Estimates indicate that as many as 18,000 different combustion products may be adsorbed onto DEPs (40).

Particle deposition studies have demonstrated that particles smaller than $2 \mu \mathrm{m}$ in diameter show a clear tendency to achieve greater peripheral deposition than those greater than $2 \mu \mathrm{m}$ in diameter (41). Regional deposition dose or local tissue burdens can vary significantly between individuals, even when total lung deposition values are comparable. It is, therefore, possible that particle burdens could reach threshold limits at local lung regions under exposure conditions that are normally acceptable, particularly in individuals with compromised lungs (42).

A few studies have addressed the immunological effects of road traffic pollution on the allergic response in humans. Most in vivo studies have looked into the effects of DEPs on the nasal mucosa. Nasal instillation of DEPs in atopic human subjects has been shown to be associated with a 25 -fold increase in $\operatorname{IgE} \mathrm{mRNA}$ and a fivefold increase in IgE levels in nasal lavage (43). DEPs induce proliferation of IgE secreting $B$ cells as well as in vivo IgE isotype switch, thereby eliciting both a quantitative and qualitative increase in IgE production (43-45). Instillation of DEPs induces upregulation of cytokine mRNA for interleukin (IL)-2, IL-4, IL-5 and granulocyte-macrophage colony-stimulating factor (GMCSF) in airway tissue (46), and, when instilled with ragweed in ragweed atopic subjects, induces more than a 50-fold increase in the allergen-specific IgE levels compared with instillation of either ragweed or DEP challenge alone (47). DEPs also associated with increased expression of mRNA for the cytokines IL-4, IL-5, IL-6, IL-10 and IL-13, and reduced expression of interferon-gamma mRNA production, suggesting that increased IgE production following DEP exposure is associated with the upregulation of T helper cell-2 specific cytokines. Peripheral blood mononuclear cells obtained from atopic subjects and cultured with DEP in vitro have been shown to increase $\operatorname{IgE}$ secretion and the number of IgE secreting B cells (48). In vitro studies on purified human tonsillar B cells cultured with volatile organic compound extracts from DEPs have demonstrated increased IgE production in the presence of costimulatory molecules such as IL-4 and CD40 (44). It has recently been demonstrated that DEPs can induce primary sensitization to a neoantigen in the human nasal mucosa by stimulating a de novo mucosal IgE response (49). Topical fluticasone treatment, which is effective in blocking local effects of allergen exposure, is unable to inhibit the adjuvant-like effects of DEPs (50). Terada et al (51) have recently demonstrated that DEPs upregulate the expression of histamine $\mathrm{H}_{1}$ receptor mRNA in human airway epithelial and endothelial cells, and enhance histamineinduced increase in IL-8 and GM-CSF production in vitro. Upregulation of histamine $\mathrm{H}_{1}$ receptors is an important factor associated with nasal and bronchial hyperresponsiveness, features characteristic of allergic rhinitis and bronchial asthma, and may, therefore, help to explain the increased incidence of asthma and rhinitis observed during particulate pollution episodes.

Intraperitoneal injection of DEPs has been reported to increase the IgE response to ovalbumin and to Japanese cedar pollen $(52,53)$. DEPs inoculated by the intranasal route act as an adjuvant activity for IgE production in mice (54). Coadministration of DEP with antigen has been shown to increase significantly the levels of IL-4 in the mediastinal lymph nodes of mice compared with instillation of antigen alone (55). Similarly, levels of the $\mathrm{T}$ helper cell-1 cytokine 
interferon-gamma have been reported to be three times lower in the cervical lymph nodes following DEP and antigen challenge than with antigen alone (56). Recently, the carbon core of the DEPs has been shown to have a significant adjuvant effect on the local immune-mediated inflammatory response as well as on the systemic specific IgE response to allergen (57), while the polycyclic aromatic hydrocarbons present in the DEP promote greater epsilon-RNA transcription and translation (44). DEPs have been reported to have an adjuvant activity in the production of $\operatorname{IgE}$ and $\operatorname{IgG} 1$ antibodies against Dermatophagoides farinae in mice immunized intranasally with mite allergen (58). Coadministration of DEPs with antigen in mice increased IL-5 protein levels up to eightfold in lung tissue and bronchoaveolar lavage supernatants compared with either antigen or DEPs alone (46). Administration of a suspension of DEPs into nasal cavities has been shown to induce nasal mucosal hyperresponsiveness to inhaled histamine in guinea pigs, along with a significant increase in vascular permeability (59). IL-4 and IL-6 production from mouse bone marrow-derived cultured mast cells was greatly increased when the cells were inoculated with allergen and DEPs compared with mast cells innoculated with allergen alone (60). Phenanthere, a major component of DEPs, has been shown to induce a threefold increase in IgE production associated with increased expression of total IgE mRNA in B cells in vitro (61). Acid sulphates present in diesel exhaust have recently been shown to increase airway hyperresponsiveness and impair mucociliary clearance (62). Recently, it has been demonstrated that DEPs by the oral ingestion route also act as mucosal adjuvants in enhancing both gut and systemic allergic immune responses, which could contribute to the development of food allergy (63).

Diesel exhaust particles have been shown to adsorb several antigens, such as ovalbumin and the grass pollen major allergen Lolp-1, onto their surface $(52,64)$ and, therefore, act as potential carriers of allergens, increasing their deposition in the respiratory tract. Thus, DEPs not only enhance the antigenicity of the allergen (65) but also increase the allergen dose reaching the lungs.

\section{REFERENCES}

1. Logan WPD. Mortality in the London fog incident, 1952. Lancet 1953;i:336-8.

2. Firket J. Sur les causes des accidents survenues dans la valle de la Meuse, lors des brouillards de December 1930. Bull Acad R Med Belg 1931;11:638.

3. Schrenk HH, Heinmann H, Claydon GD, Gafarar WM, Wexler H. Air pollution. In: Donora PA, ed. Epidemiology of the Unusual Smog Episode of October 1948, Public Health Bulletin No 306. Washington, DC: Public Health Service, 1949.

4. Guidotti TL. Ambient air quality and human health: Current concepts. Part I. Can Respir J 1995;2:211-22.

5. United Nations. Prospects of World Urbanization 1988, Population studies No 112. New York: United Nations 1989.

6. Bascom R. Environmental factors and respiratory hypersensitivity: the Americas. Toxicol Lett 1996;86:115-30.

7. Burr ML. Pollution: does it cause asthma? Arch Dis Child 1995;72:377-9.

8. Devalia JL, Bayram H, Rusznak C, et al. Mechanisms of pollution-induced airway disease: in vitro studies in the upper and lower airways. Allergy 1997;52(Suppl 38):45-51.
Short term inhalation of DEPs has been shown to increase the numbers of neutrophils in the bronchial epithelium, submucosa, airway lavage and peripheral blood of healthy human subjects (66). This is mediated by enhanced gene transcription and protein production of the chemokines IL- 8 and growth-related oncogene- $\alpha$ by bronchial epithelial cells (67). Ultrafine particles present in diesel exhaust generate reactive oxygen species that activate the transcription factor nuclear factor-kappa B to induce gene transcription of several proinflammatory mediators (68). Phagocytosis of $\mathrm{PM}_{10}$ by alveolar macrophages has been shown to stimulate the release of polymorphonuclear leukocytes from bone marrow (69). Intratracheal administration of particles has been shown to aggravate allergeninduced airway inflammation involving eosinophils, lymphocytes and mucus producing cells (46). These cells are believed to play a major role in the pathogenesis of allergic airway diseases. PM10-induced enhanced allergic responses, therefore, appear to be mediated by the generation of various proinflammatory mediators.

\section{CONCLUSIONS}

The rapid increase in the prevalence of allergic diseases may be explained by changes occurring in the environment. Epidemiological studies indicate that the sharp rise in air pollution from motor vehicles may be considered an important risk factor for this increase. Laboratory data support the hypothesis that pollutants emitted from motor vehicle exhausts play a role in the long term increases in the prevalence of allergic airway diseases. Although the detrimental effects of air pollution on human health have been brought to public attention, it appears that less attention has been given to the potential role of road traffic fumes in the induction of the allergic state. Pollutants that enhance the airway allergic antibody response can be now identified, and appropriate measures can be taken to decrease the levels of these compounds in our cities. Thus, legislators should seriously consider pollutants emitted from motor vehicle exhausts as a potential pro-allergic hazard before making important changes in environmental policy.
9. Dockery DW, Pope AC III, Xu X, et al. An association between air pollution and mortality in six U.S. cities. N Engl J Med 1993;329:1753-9.

10. Salvi SS, Frew A, Holgate S. Is diesel exhaust a cause for increasing allergies? Clin Exp Allergy 1999;29:4-8.

11. Ishizaki T, Koizumi K, Ikemori R, Ishiyama Y, Kushibiki E. Studies of prevalence of Japanese cedar pollinosis among the residents in a densely cultivated area. Ann Allergy 1987;58:265-70.

12. Yokoyama Y, Nitta H, Maeda K, Aoki S. What interaction does indoor nitrogen dioxide have on the effect of the automobile exhaust. Tokai $\mathrm{J}$ Exp Clin Med 1985;10:379-84.

13. Ono M, Murakami M, Nitta H, Nakai S, Maeda K. [Epidemiological studies of air pollution and health effects in areas near roadways with heavy traffic in Tokyo.] Nippon Koshu Eisei Zasshi 1990;37:321-32.

14. van Vliet P, Knape M, de Hartog J, Janssen N, Harssema H, Brunekreef B. Motor vehicle exhaust and chronic respiratory symptoms in children living near freeways. Environ Res 1997;74:122-32.

15. Oosterlee A, Drijver M, Lebret E, Brunekreef B. Chronic respiratory symptoms in children and adults living along streets with high traffic density. Occup Environ Med 1996;53:241-7. 
16. Vedal S, Petkau J, White R, Blair J. Acute effects of ambient inhalable particles in asthmatic and nonasthmatic children. Am J Respir Crit Care Med 1998;157:1034-43.

17. Edwards J, Walters S, Griffiths RK. Hospital admissions for asthma in preschool children: relationship to major roads in Birmingham, United Kingdom. Arch Environ Health 1994;49:223-7.

18. Roemer W, Hoek G, Brunekreef B. Effect of ambient winter air pollution on respiratory health of children with chronic respiratory symptoms. Am Rev Respir Dis 1993;147:118-24.

19. Wjst M, Reitmeir P, Dold S, et al. Road traffic and adverse effects on respiratory health in children. BMJ 1993;307:596-600.

20. Forastiere F, Corbo GM, Pistelli R, et al. Bronchial responsiveness in children living in areas with different air pollution levels. Arch Environ Health 1994;49:111-8.

21. Horstman D, Kotesovec F, Vitnerova N, et al. Pulmonary functions of school children in highly polluted northern Bohemia. Arch Environ Health 1997;52:56-62

22. Yang SC, Yang SP. Respiratory function changes from inhalation of polluted air. Arch Environ Health 1994;49:182-7.

23. Livingstone AE, Shaddick G, Grundy C, Elliott P. Do people living near inner city main roads have more asthma needing treatment? Case control study. BMJ 1996;312:676-7.

24. Waldron G, Pottle B, Dod J. Asthma and the motorways - one District's experience. J Public Health Med 1995;17:85-9.

25. Brunekreef B, Janssen NA, de Hartog J, Harssema H, Knape M, van Vliet P. Air pollution from truck traffic and lung function in children living near motorways. Epidemiology 1997;8:298-303.

26. Weiland SK, Mundt KA, Ruckmann A, Keil V. Self-reported wheezing and allergic rhinitis in children and truck traffic density on streets of residence. Ann Epidemiol 1994;4:243-7.

27. Ciccone G, Forastiere F, Agabiti N, et al. Road traffic and adverse respiratory effects in children. SIDRIA Collaborative Group. Occup Environ Med 1998;55:771-8.

28. Nakai S, Nitta H, Maeda K. Respiratory health associated with exposure to automobile exhaust. III. Results of a cross-sectional study in 1987, and repeated pulmonary function tests from 1987 to 1990 . Arch Environ Health 1999;54:26-33.

29. Duhme H, Weiland SK, Keil U, et al. The association between self-reported symptoms of asthma and allergic rhinitis and self-reported traffic density on street of residence in adolescents. Epidemiology 1996;7:578-82.

30. Pershagen G, Rylander E, Norberg S, Eriksson M, Nordvall SL. Air pollution involving nitrogen dioxide exposure and wheezing bronchitis in children. Int J Epidemiol 1995;24:1147-53.

31. Boezen HM, van der Zee SC, Postma DS, et al. Effects of ambient air pollution on upper and lower respiratory symptoms and peak expiratory flow in children. Lancet 1999;353:874-8.

32. Elliott P, Briggs D, Lebret E, Gorynski P, Kriz B. Small area variations in air quality and health (the SAVIAH study): design and methods. Epidemiology 1995;6(Suppl):S32. (Abst)

33. von Mutius E, Fritzsch C, Weiland SK, Roll G, Magnussen H. Prevalence of asthma and allergic disorders among children in united Germany: a descriptive comparison. BMJ 1992;305:1395-9.

34. Braback L, Breborowicz A, Dreborg S, Knutsson A, Pieklik H, Bjorksten B. Atopic sensitization and respiratory symptoms among Polish and Swedish school children. Clin Exp Allergy 1994;24:826-35.

35. Gergen PJ, Turkeltaub PC, Kovar MG. The prevalence of allergic skin test reactivity to eight common aeroallergens in the U.S. population: results from the second National Health and Nutrition Examination Survey. J Allergy Clin Immunol 1987;80:669-79.

36. Popp W, Zwick H, Steyrer K, Raushner H, Wanke T. Sensitization to aeroallergens depends on environmental factors. Allergy 1989;44:572-5.

37. Braback L, Kalvesten L. Urban living as a risk factor for atopic sensitization in Swedish school children. Pediatr Allergy Immunol 1992;2:14-9.

38. Polosa R, Russo S, Sciuto R, et al. Increased prevalence for allergic sensitisation in a high risk group exposed to road traffic fumes: a pilot study. Eur Respir J 1999. (In press)

39. Kerminen VM, Makela TE, Ojanen C. Characterization of the particulate phase in the exhaust from a diesel car. Environ Sci Technol 1997;31:1883-9.

40. Weisenberger B. Health effects of diesel emissions: a current status report. J Soc Occup Med 1981;34:4-8.

41. Anderson M, Svartengren M, Philipson K, Cramer P. Regional deposition studied by repeated investigations. J Aerosol Sci 1988;19:1121-4.

42. Kim CS, Hu SC. Regional deposition of inhaled particles in human lungs: comparison between men and women. J Appl Physiol 1998;84:1834-44.

43. Diaz-Sanchez D, Dotson AR, Takenaka H, Saxon A. Diesel exhaust particles induce local IgE production in vivo and alter the pattern of IgE messenger RNA isoforms. J Clin Invest 1994;94:1417-25.

44. Takenaka H, Zhang K, Diaz-Sanchez D, Tsien A, Saxon A. Enhanced human IgE production results from exposure to the aromatic hydrocarbons from diesel exhaust: direct effects on B-cell IgE production. J Allergy Clin Immunol 1995;95:103-15.

45. Fujieda S, Diaz-Sanchez D, Saxon A. Combined nasal challenge with diesel exhaust particles and allergen induces in vivo IgE isotype switching. Am J Respir Cell Mol Biol 1998;19:507-12.

46. Takano H, Yoshikawa T, Ichinose T, Miyabara Y, Imaoka K, Sagai M. Diesel exhaust particles enhance antigen-induced airway inflammation and local cytokine expression in mice. Am J Respir Crit Care Med 1997; 156:36-42.

47. Diaz-Sanchez D, Tsien A, Fleming J, Saxon A. Combined diesel exhaust particulate and ragweed allergen challenge markedly enhances human in vivo nasal ragweed-specific IgE and skews cytokine production to a T helper cell 2-type pattern. J Immunol 1997; $158: 2406-13$

48. Pftutzner W, Thomas P, Przybilla B. Influence of suspended diesel exhaust particles (DEP) in number and activity of IgE secreting cells in vitro. J Allergy Clin Immunol 1995;95:335. (Abst)

49. Wang M, Saxon A, Diaz-Sanchez D. Diesel exhaust particles can induce sensitization to a de novo allergen in the human mucosa. J Allergy Clin Immunol 1999;103:A341. (Abst)

50. Diaz-Sanchez D, Tsien A, Fleming J, Saxon A. Effect of topical fluticasone propionate on the mucosal allergic response induced by ragweed allergen and diesel exhaust particle challenge. Clin Immunol 1999;90:313-22

51. Terada N, Hamano N, Maesako KI, et al. Diesel exhaust particulates upregulate histamine receptor mRNA and increase histamine-induced IL-8 and GM-CSF production in nasal epithelial cells and endothelial cells. Clin Exp Allergy 1999;29:52-9.

52. Takafuji S, Suzuki S, Koizumi K, et al. Enhancing effect of suspended particulate matter on the IgE antibody production in mice. Int Arch Allergy Appl Immunol 1989;90:1-7.

53. Suzuki T, Kanoh T, Kanbayashi M, Todome Y, Ohkuni H. The adjuvant activity of pyrene in diesel exhaust on $\operatorname{IgE}$ antibody production in mice. Arerugi 1993;42:963-8.

54. Takafuji S, Suzuki S, Koizumi K, et al. Diesel-exhaust particulates inoculated by the intranasal route have an adjuvant activity for $\operatorname{IgE}$ production in mice. J Allergy Clin Immunol 1987;79:639-45.

55. Fujimaki H, Nohara O, Ichinose T, Watanabe N, Saito S. IL-4 production in mediastinal lymph node cells in mice intratracheally instilled with diesel exhaust particulates and antigen. Toxicology 1994;92:261-8

56. Fujimaki H, Saneyoshi K, Nohara O, Shiraishi F, Imai T. Intranasal instillation of diesel exhaust particulates and antigen in mice modulated cytokine productions in cervical lymph node cells. Int Arch Allergy Immunol 1995;108:268-73.

57. Lovik M, Hogseth AK, Gaarder PI, Hagemann R, Eide I. Diesel exhaust particles and carbon black have adjuvant activity on the local lymph node response and systemic IgE production to ovalbumin. Toxicology 1997; 121:165-78.

58. Suzuki T, Kanoh T, Ishimori M, Ikeda S, Ohkuni H. Adjuvant activity of diesel exhaust particulates (DEP) in production of anti-IgE and anti-IgG1 antibodies to mite allergen in mice. J Clin Lab Immunol 1996;48:187-99.

59. Kobayashi T, Ikeue T, Ikeda A. Four-week exposure to diesel exhaust induces nasal mucosal hyperresponsiveness to histamine in guinea pigs. Toxicol Sci 1998;45:106-12.

60. Saneyoshi K, Nohara O, Imai T, Shiraishi F, Moriyama H, Fujimaki H. IL-4 and IL-6 production of bone marrow-derived mast cells is enhanced by treatment with environmental pollutants. Int Arch Allergy Immunol 1997;114:237-45.

61. Tsien A, Diaz-Sanchez D, Ma J, Saxon A. The organic component of diesel exhaust particles and phenanthrene, a major polyaromatic hydrocarbon constituent, enhances IgE production by IgE-secreting EBV-transformed human B cells in vitro. Toxicol Appl Pharmacol 1997;142:256-63.

62. el-Fawal HA, McGovern T, Schlesinger RB. Nonspecific bronchial 
responsiveness assessed in vitro following acute inhalation exposure to ozone and ozone/sulfuric acid mixtures. Exp Lung Res 1995;21:129-39.

63. Yoshino S, Sagai M. Induction of systemic Th1 and Th2 immune responses by oral administration of soluble antigen and diesel exhaust particles. Cell Immunol 1999;192:72-8.

64. Knox RB, Suphioglu C, Taylor P, et al. Major grass pollen allergen Lol $p 1$ binds to diesel exhaust particles: implications for asthma and air pollution. Clin Exp Allergy 1997;27:246-51.

65. Frew AJ, Salvi SS. Diesel exhaust particles and respiratory allergy. Clin Exp Allergy 1997;27:237-9.

66. Salvi S, Blomberg A, Rudell B, et al. Acute inflammatory responses in the airways and peripheral blood after short-term exposure to diesel exhaust in healthy human volunteers. Am J Respir Crit Care Med 1999;159:702-9.

67. Salvi S, Nordenhall C, Blomberg A, et al. Short-term exposure to diesel exhaust induces IL-8 and GRO-a production in the airways of healthy human subjects. Am J Respir Crit Care Med 1999. (In press)

68. Takizawa H, Ohtoshi T, Kawasaki S, et al. Diesel exhaust particles induce NF-kappa B activation in human bronchial epithelial cells in vitro: importance in cytokine transcription. J Immunol 1999;162:4705-11.

69. Terashima T, Wiggs B, English D, Hogg JC, van Eeden SF. Phagocytosis of small carbon particles (PM10) by alveolar macrophages stimulates the release of polymorphonuclear leukocytes from bone marrow. Am J Respir Crit Care Med 1997; 155:1441-7. 


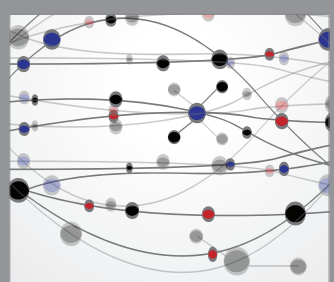

The Scientific World Journal
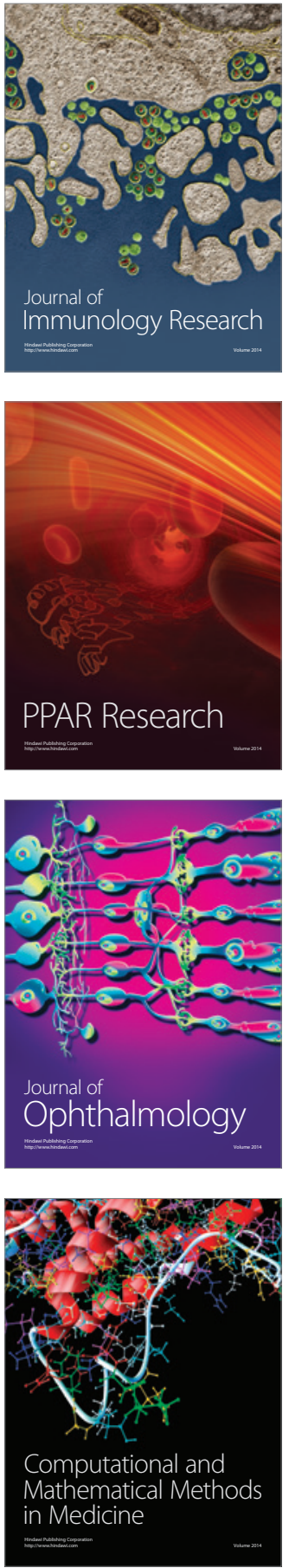

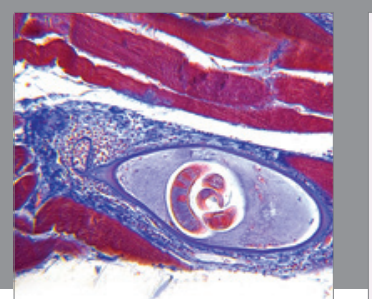

Gastroenterology Research and Practice

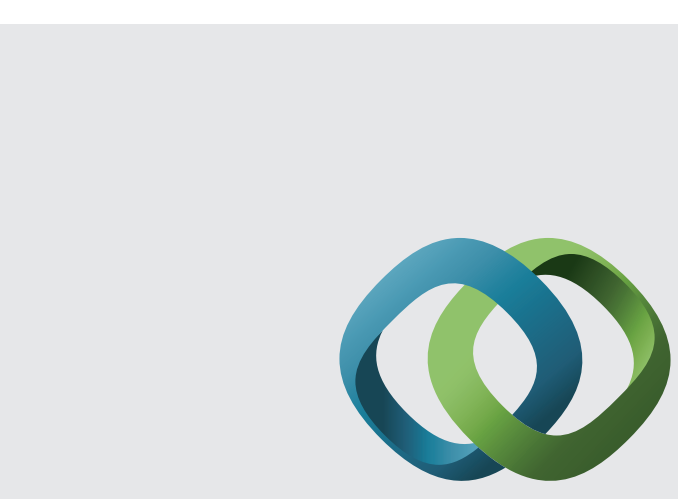

\section{Hindawi}

Submit your manuscripts at

http://www.hindawi.com
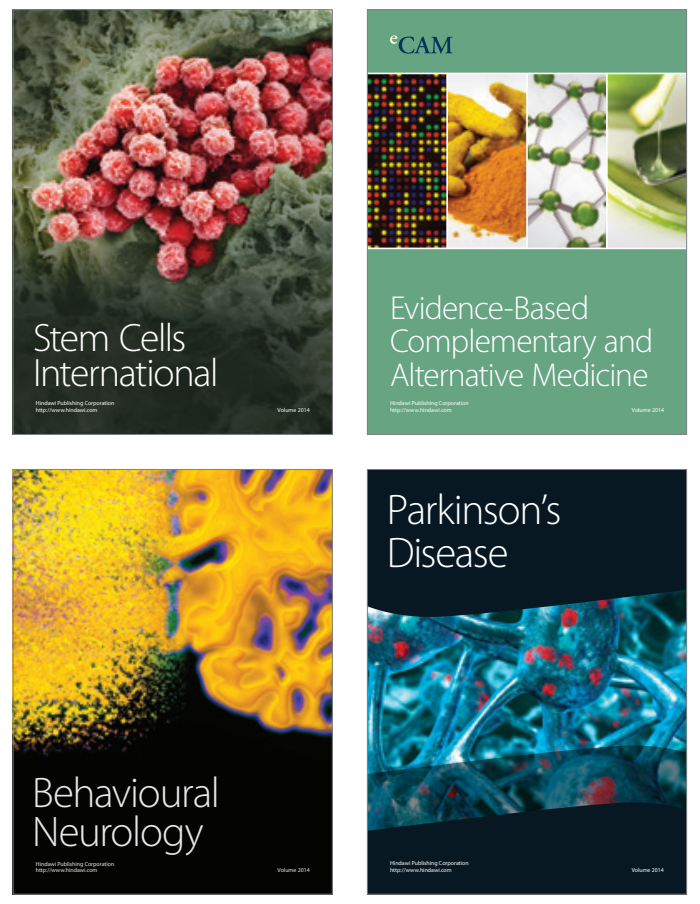
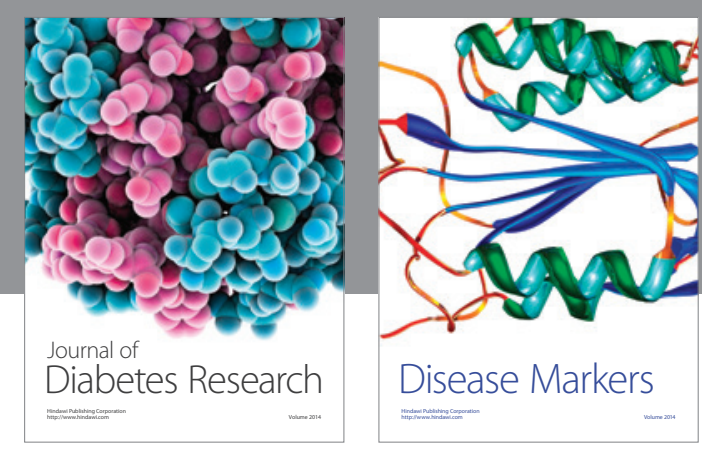

Disease Markers
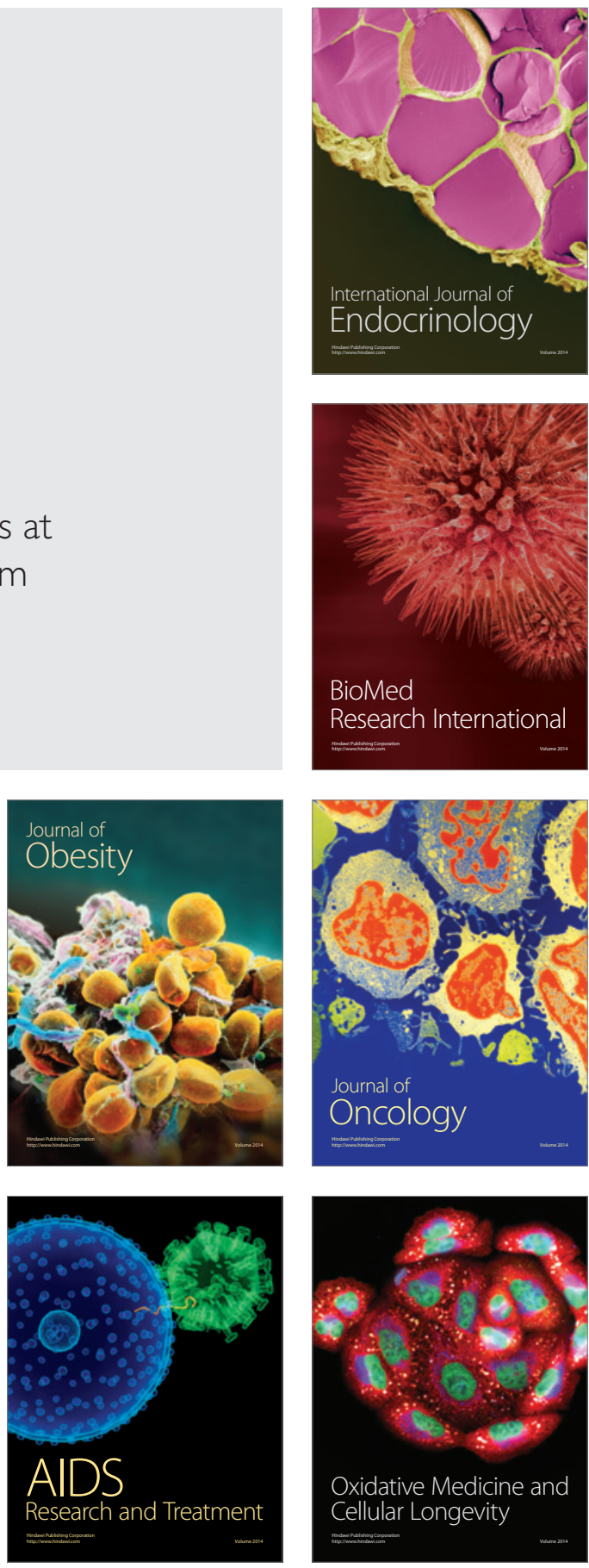